\title{
PENGARUH PEMAHAMAN PERATURAN, OMSET, PEMERIKSAAN, SANKSI, RELASI SOSIAL, DAN PERSAINGAN USAHA TERHADAP KEPATUHAN WAJIB PAJAK RESTORAN
}

\author{
Ramadhan S S Manafe ${ }^{1}$ \\ arimanaf07@gmail.com \\ Aaron M. A. Simanjuntak, SE., M.Si., CBV., CMA ${ }^{2}$ \\ Hastutie N. Andriati, SE., M.Si., Ak., $\mathrm{CA}^{3}$ \\ Jurusan Akuntansi, Fakultas Ekonomi dan Bisnis Universitas Cenderawasih
}

\begin{abstract}
The research aims to determine the factors that influence the taxpayer compliance with the restaurant in Jayapura in fulfilling its obligations to deposit the restaurant tax. Factors used among others: Regulatory understanding, turnover, investigations, sanctions, social relations, and business competition. The number of respondents used in this study is 100 mandatory the registered restaurant tax at Jayapura's regional revenue Service. Techniques the analysis used is a double linear regression technique. The results showed that the regulatory understanding factors, of income/turnover, significantly affect the taxpayer's compliance Restaurant. While the sanctions, investigations, social relations, and business competition factors Taxpayer compliance with the restaurant in Jayapura City.
\end{abstract}

Keywords : turnover, sanctions, social relations, fulfillment of taxation obligation, restaurants.

\section{PENDAHULUAN}

Pendapatan daerah ialah salah satu sumber yang paling penting yang digunakan untuk mendukung pelaksanaan Pemerintahan Daerah dalam meningkatkan pelayanannya pada masyarakat serta memandirikan daerah tersebut. Pendapatan daerah menurut Arviana \& Sadjiarto (2014) ialah hak daerah yang diakui menjadi penambah nilai kekayaan bersih atau pendapatan pada periode anggaran tahun tertentu. Sidik (2002) menambahkan pendapatan daerah bersumber dari penerimaan dan perimbangan pusat serta daerah, pendapatan asli daerah (PAD), dan pendapatan lain-lain yang sah. Menurut Arviana \& Sadjiarto (2014) PAD adalah sumber-sumber keuangan yang diperoleh dari daerah yang terdiri dari bantuan hasil pajak daerah, retribusi daerah, pengelolaan kekayaan daerah yang dipisahkan dan pendapatan lain-lain asli daerah yang jelas.

Menurut Adiningrat, Subhan, \& Nur (2017) pajak restoran merupakan salah satu sumber pendapatan daerah. Pajak restoran menurut Pratama, Saifi, \& ZA (2016) ialah pajak atas pelayanan yang disediakan oleh pihak restoran. Menurut PERDA Kota Jayapura (2012) tentang pajak restoran, besarnya tarif pajak restoran ialah 10\% (sepuluh persen). Sesuai dengan Peraturan Daerah dikalikan dengan jumlah pembayaran yang diterima atau seharusnya diterima restoran. Dalam PERDA Kota Jayapura (2012) wajib pajak restoran adalah orang pribadi atau badan yang mengusahakan restoran tersebut.

\footnotetext{
${ }^{1}$ Alumni Jurusan Akuntansi FEB Uncen

${ }^{2}$ Dosen Jurusan Akuntansi FEB Uncen

3 Dosen Jurusan Akuntansi FEB Uncen
} 
Dalam pelaksanaan pemungutan pajak restoran oleh Badan Pendapatan Daerah Kota Jayapura sering ditemuinya Wajib Pajak Restoran yang tidak memenuhi kewajiban perpajakannya secara tepat waktu. Pihak pemungut yaitu Bapenda harus memberikan surat teguran bahkan sanksi untuk para ajib pajak agar mereka sesegara mungkin menyelesaikan kewajiban perpajakannya. Dari fenomena tersebut peneliti ingin melihat hal-hal apa saja yang dapat mendorong wajib pajak agar patuh dalam membayar pajak restorannya.

Dalam penelitian ini, faktor-faktor yang diuji oleh peneliti ialah pemahaman peraturan Pajak Restoran, omset, pemeriksaan, penerapan sanksi pajak, relasi sosial sesama wajib pajak restoran, dan persaingan sesama wajib pajak restoran terhadap kepatuhan wajib pajak dalam membayar pajak restoran yang berada di Kota Jayapura pada tahun 2019. Dimana tujuan dari penelitian ini adalah untuk menganalisa pengaruh pemahaman pajak, besarnya omset restoran, pemeriksaan wajib pajak, sanksi pajak, relasi sosial sesama wajib pajak dan persaingan usaha wajib pajak terhadap kepatuhan wajib pajak.

\section{TINJAUAN PUSTAKA}

\subsection{Theory of Planned behavior}

Menurut Nugroho (2012) perilaku yang ditampilkan oleh individu timbul karena adanya niat untuk berprilaku. Nugroho (2012) menambahkan hal-hal yang dapat menghambat saat prilaku ditampilkan dapat berasal dari dalam diri atau lingkungan luar. Secara berurutan, behavioral beliefs menghasilkan sikap positif atau negatif pada suatu objek. Sedangkan normatif beliefs menghasilkan tekanan sosial yang dipersepsikan atau norma subjektif. Dan control beliefs menimbulkan kontrol keprilakuan yang dipersepsikan.

Theory planned behavior sesuai bila digunakan untuk menjelaskan perilaku wajib pajak dalam memenuhi kewajiban pajaknya. Hal tersebut berkaitan dengan pemahaman wajib pajak mengenai peraturan perpajakan.wajib pajak yang memahami peraturan perpajakan, akan memiliki prinsip tentang pentingnya membayar pajak untuk memenuhi segala kewajiban perpajakan dengan benar.

\subsection{Pajak Restoran}

Salah satu jenis pajak daerah adalah pajak restoran. Pajak restoran dapat digolongkan dalam pajak tidak langsung, dimana pajak yang pengenaannya berdasarkan atas pelayanan yang diberikan kepada konsumen, dan bebannya diberatkan kepada konsumen tersebut. Dalam hal ini, pemilik/pengusaha restoran adalah pihak yang melakukan pemungutan dan hasilnya akan disetorkan kepada instansi yang berwenang dalam pengumpulan hasil pajak.

Menurut PERDA Kota Jayapura (2012) pajak restoran adalah jumlah pembayaran yang diterima atau yang seharusnya diterima Restoran. Dalam PERDA Kota Jayapura (2012) restoran adalah fasilitas penyedia makanan dan atau minuman dengan dipungut bayaran, yang mencakup juga rumah makan, kafetaria, kantin, warung, bar dan sejenis termasuk jasa boga/catering.

PERDA Kota Jayapura (2012) juga mengatur subjek pajak restoran adalah orang pribadi atau Badan yang membeli makanan dan/atau minuman di restoran. Wajib pajak restoran adalah orang pribadi adalah orang pribadi atau badan yang mengusahakan Restoran. Dasar pengenaan Pajak Restoran adalah jumlah pembayaran yang diterima atau yang seharusnya diterima Restoran. Besarnya tarif pajak restoran ditetapkan sebesarnya $10 \%$ (sepuluh persen). Besaran pajak restoran yang terutang dihitung dengan cara mengalihkan tarif pengeneaan pajak restoran dengan besar tarif pajak restoran. 


\subsection{Pemahaman Wajib Pajak}

Pemahaman wajib pajak atas peraturan perpajakan merupakan cara wajib pajak dalam mengetahui peraturan yang telah ada. Seorang wajib pajak yang memahami peraturan perpajakan dengan baik dan jelas akan lebih taat dalam memenuhi kewajibannya dibandingkan wajib pajak yang tidak memahami peraturan perpajakan. Pengelolaan pajak telah diatur dalam peraturan perpajakan namun pelaksanaannya kurang efektif dikarenakan faktor hukum yang tidak menjelaskan secara lengkap tentang perhitungan pajak restoran dan masih sempitnya pengetahuan wajib pajak akan peraturan yang berlaku disebabkan kurangnya sosialisasi dari pemerintah kepada wajib pajak. Menurut Oroh (2013) pemahaman wajib pajak atas peraturan perpajakan berpengaruh signifikan terhadap kepatuhan wajib pajak dalam melaporkan kewajiban perpajakannya. Namun hasil itu bertolak belakang dengan penelitian yang dilakukan oleh Nurlaela (2014) yang menunjukkan pemahaman peraturan perpajakan kurang berpengaruh terhadap kepatuhan wajib pajak. Hal tersebut menunjukkan bahwa responden belum sadar bahwa pembayaran pajak merupakan suatu hal yang penting.

\subsection{Omset}

Omset adalah jumlah hasil penjualan barang (dagangan) tertentu selama masa menjual. Wajib pajak restoran dianggap patuh apabila melaporkan jumlah omset atau penghasilan bruto sesuai dengan penghasilan yang diterima. Omset merupakan salah salah satu faktor yang memengaruhi kepatuhan wajib pajak restoran. Besarnya tarif pajak yang ditetapkan dari jumlah omset menyebabkan wajib pajak cenderung merasa keberatan, sehingga wajib pajak memilih menyembunyikan jumlah omset penjualan yang sebenarnya agar pajak yang dibayar tidak terlalu besar. Hal itu sejalan dengan penelitian yang dilakukan oleh Arviana \& Sadjiarto (2014) yaitu omset berpengaruh terhadap kepatuhan wajib pajak. Sedangkan, menurut Rizajayanti (2017) omset tidak berpengaruh terhadap kepatuhan wajib pajak.

\subsection{Pemeriksaan}

Pemeriksaan merupakan suatu tindakan mengumpulkan serta mengolah data, keterangan, dan bukti yang dilakukan secara objektif dan kompeten berdasarkan standar pemeriksaan yang berlaku untuk melihat kepatuhan pemenuhan kewajiban perpajakan berdasarkan peraturan yang berlaku. Dengan adanya pemeriksaan rutin diharapkan dapat mendorong niat wajib pajak dalam memenuhi kewajibannya. Kendala dalam melakukan pemeriksaan ialah jumlah petugas yang tidak sebanding dengan banyaknya restoran yang ada. Sehingga pelaksanaan pemeriksaan kurang berdampak pada kepatuhan wajib wajib pajak. Menurut Ratna sari \& Afriyanti (2012) dilakukannya pemeriksaan dapat berpengaruh terhadap kepatuhan wajib pajak dalam memenuhi kewajibannya. Sedangkan, menurut Arviana \& Sadjiarto (2014) pemeriksaan tidak mempengaruhi tingkat kepatuhan wajib pajak dalam memenuhi kewajiban perpajakannya.

\subsection{Sanksi Perpajakan}

Sanksi perpajakan adalah jaminan yang digunakan sebagai penentu bahwa peraturan perundang-undangan akan dilakukan tanpa adanya pelanggaran yang dilakukan oleh wajib pajak. Sanksi perpajakan merupakan suatu usaha untuk mencegah agar wajib pajak tidak melanggar peraturan yang berlaku. Sanksi pajak yang diberikan atas kecurangan yang dilakukan wajib pajak menunjukkan sikap pemerintah dalam menanggapi kecurangan. Sanksi pajak akan lebih merugikan wajib pajak sehingga wajib pajak akan lebih patuh dalam kewajiban perpajakannya. Menurut Jaya \& Jati (2016) sanksi pajak dapat mempengaruhi kepatuhan wajib pajak. Sedangkan, menurut Rizajayanti (2017) sanksi pajak tidak mempengaruhi tingkat kepatuhan wajib pajak. 


\subsection{Relasi Sosial}

Relasi sosial menurut KBBI (2014) adalah hubungan timbal balik yang merupakan aksi saling memengaruhi antara individu atau antar kelompok. Menurut Arviana \& Sadjiarto (2014) adanya relasi sosial memungkinkan adanya pengaruh yang diberikan dari wajib pajak yang satu kepada wajib pajak yang lain dalam memenuhi kewajiban perpajakannya. Para pemilik usaha akan memenuhi kewajibannya dengan baik apabila dia melihat pemilik yang lain juga melakukan hal yang sama. Menurut Arviana \& Sadjiarto (2014) relasi sosial tidak berpengaruh terhadap kepatuhan wajib pajak. Sedangkan menurut Bobek \& Hatfield (2008) relasi sosial dapat mempengaruhi perilaku kepatuhan wajib pajak.

\subsection{Persaingan}

Persaingan menurut Arviana \& Sadjiarto (2014) adalah suatu proses dimana kelompok atau individu bersaing mencari keuntungan di bidang-bidang kehidupan yang pada satu masa tertentu menjadi fokus utama dengan cara menarik perhatian publik atau dengan mengasah kemampuan dalam inovasi dan kreativitas tanpa melakukannya dengan ancaman yang merujuk pada kekerasan atau kriminalitas. Dalam dunia perbisnisan hal yang sering muncul adalah persaingan ekonomi yang muncul karena terbatasnya konsumen dibandingkan dengan jumlah persediaan yang ada. Jumlah restoran yang selalu meningkat menyebabkan tingginya persaingan dalam menarik konsumen. Menurut pengalaman peneliti sebelumnya ada beberapa restoran yang tidak menarik pajak restoran dan pemilik menyatakan bahwa pajak restoran di bayar sendiri oleh pemilik tanpa membebankan pada konsumen. Pemilik mengatakan bahwa persaingan harga menuntut pemilik untuk membayar pajak restoran sendiri karena kebanyakan konsumen tidak mau untuk membayar pajak restoran dan banyak dari konsumen lebih memilih restoran yang tidak menambahkan nilai pajak restoran.

\subsection{Kepatuhan Wajib Pajak}

Menurut Jatmiko (2006) kepatuhan adalah motivasi seseorang, kelompok atau organisasi untuk berbuat atau tidak berbuat sesuai dengan aturan yang di tetapkan. Dalam pajak, aturan yang berlaku adalah Undang-Undang Perpajakan jadi kepatuhan pajak adalah kepatuhan seseorang terhadap peraturan UndangUndang Perpajakan.

Nurmantu (2010) berpendapat kepatuhan perpajakan merupakan suatu keadaan dimana wajib pajak memenuhi semua kewajibannya dan melaksanakan hak perpajakannya. Menurut Rizajayanti (2017) Kepatuhan perpajakan dapat didefinisikan sebagai suatu keadaan dimana Wajib Pajak memenuhi semua kewajiban perpajakan danmelaksanakan hak perpajakannya.

\subsection{Penelitian Terdahulu dan Pengembangan Hipotesis}

\section{Pengaruh Pemahaman Wajib Pajak terhadap Kepatuhan Wajib Pajak}

Menurut Hardiningsih \& Yulianawati (2011) apabila wajib pajak tidak memahami peraturan perpajakan secara jelas maka akan menciptakan wajib pajak yang tidak taat akan peraturan. Arviana $\&$ Sadjiarto (2014) menyatakan bahwa pengelolaan pajak restoran telah diatur dengan peraturan yang berlaku, namun belum efektif karena kendala faktor hukum yang belum menjelaskan secra terperinci tentang cara perhitungan pajak restoran serta kurangnya sosialisasi kepada wajib pajak restoran. Menurut Oroh (2013) menyatakan bahwa pengetahuan dan pemahaman wajib pajak atas peraturan berpengaruh signifikan terhadap kepatuhan wajib pajak dalam melaporkan kewajiban pajakannya. Kumalayani et al. (2016) menambahkan pemahaman berpengaruh terhadap kepatuhan wajib pajak. Maka patut diduga: 


\section{Pengaruh Omset terhadap Kepatuhan Wajib Pajak Restoran}

Menurut Arviana \& Sadjiarto (2014) wajib pajak restoran dianggap patuh apabila melaporkan jumlah omset atau penghasilan bruto sesuai dengan penghasilan yang diterima. Namun, masih banyak wajib pajak yang yang menganggap bahwa adanya pajak restoran akan mempengaruhi pendapatan yang seharusnya mereka terima. Sehingga dikarenkan alasan tersebut banyak wajib pajak restoran yang tidak melaporkan pajaknya agar penghasilan yang diterimanya tidak terpotong. Arviana \& Sadjiarto (2014) menunjukkan bahwa omset mempengaruhi kepatuhan wajib pajak. Maka diduga bahwa:

\section{H2: Omset berpengaruh terhadap kepatuhan wajib pajak.}

\section{Pengaruh Pemeriksaan terhadap Kepatuhan Wajib Pajak Restoran}

Pemeriksaaan adalah kegiatan mengumpulkan mengola data, keterangan atau bukti yang dilakukan secara objektif dan profesional berdasarkan standart pemeriksaan untuk menguji kepatuhan pemenuhan kewajiban perpajakan untuk tujaan dalam rangka melaksanakan ketentuan peraturan perundang-undang perpajakan, berkendala di petugas yang tidak sebanding dengan jumlah restoran yang banyak. Dengan pemeriksaan akan mendorong wajib pajak lebih patuh memenuhi tanggung jawab perpajakan. Menurut Ratna sari \& Afriyanti (2012) pemeriksaan berpengaruh signifikan terhadap kepatuhan wajib pajak dalam pemenuhan kewajibannya selaku wajib pajak. Maka diduga bahwa:

\section{H3 : Pemeriksaan berpengaruh terhadap kepatuhan wajib pajak}

\section{Pengaruh Sanksi Perpajakan terhadap Kepatuhan Pajak Restoran}

Sanksi pajak merupakan jaminan bahwa ketentuan peraturan perundangundangan perpajakan akan dipatuhi sebagai alat pencegah agar wajib pajak tidak melanggar norma atau peraturan perpajakan. Sanksi perpajakan dianggap memberikan kerugian terhadap wajib pajak sehingga mereka akan selalu berusaha untuk menghindarinya. Hal ini membuat para wajib pajak untuk patuh dalam membayar kewajiban perpajaknnya. Arviana \& Sadjiarto (2014) menunjukkan bahwa sanksi perpajakan berpengaruh secara positif terhadap kepatuhan wajib pajak. Dalam penelitian lainnya seperti yang dilakukan oleh Jaya \& Jati (2016) menyatakan bahwa sanksi perpajakan berpengaruh terhadap kepatuhan wajib pajak. Maka diduga bahwa:

H4: Sanksi perpajakan berpengaruh terhadap kepatuhan wajib pajak.

\section{Pengaruh Relasi Sosial terhadap Kepatuhan Wajib Pajak}

Relasi sosial menurut KBBI (2014) Merupakan hubungan timbal balik berupa aksi saling mempengaruhi antara individu dan individu, antara individu dengan kelompok, danatar kelompok dengan kelompok lain. Menurut penelitian Tjahyono (2017) Relasi sosial memungkinan membawa pengaruh yang diberikan dari wajib pajak yang satu kepada wajib pajak yang lain termasuk dalam memenuhi fungsi perpajakannya. Melalui wawancara beberapa pemilik usaha menyatakan apabila wajib pajak lain membayar sesuai dengan yang diperoleh maka pemilik usaha akan membayar sesuai yang diperoleh, Bobek, Hageman, \& Hatfield (2010) anggota keluarga, pimpinan perusahaan, teman, pasangan, peran penting memprediksi prilaku wajib pajak. Menurut Arviana \& Sadjiarto (2014) relasi sosial tidak berpengaruh terhadap kepatuhan wajib pajak. Maka diduga bahwa:

H5: Relasi sosial berpengaruh terhadap kepatuhan wajib pajak restoran. 


\section{Pengaruh Persangingan terhadap Kepatuhan Wajib Pajak}

Persaingan meneurut Arviana \& Sadjiarto (2014) adalah suatu proses sosial dimana kelompok atau individu bersaing mencari keuntungan di bidangbidang kehidupan yang pada satu masa tertentu menjadi fokus utama dengan cara menarik perhatian publik atau dengan mengasah kemampuan dalam inovasi dan kreartifitas tanpa melakukannya dengan ancaman yang merujuk pada kekerasan atau kriminalitas. Menurut pengalaman peneliti sebelumnya ada beberapa restoran yang tidak menarik pajak restoran dan pemilik menyatakan bahwa pajak restoran di bayar sendiri oleh pemilik tanpa membebankan pada konsumen. Pemilik mengatakan bahwa persaingan harga menuntut pemilik untuk membayar pajak restoran sendiri karena kebanyakan konsumen tidak mau untuk membayar pajak restoran dan banyak dari konsumen lebih memilih restoran yang tidak menambahkan nilai pajak restoran. Maka diduga bahwa:

H6: Pengaruh persaingan usaha terhadap kepatuhan wajib pajak

\subsection{Model Penelitian}

\section{Gambar 1}

Kerangka Pemikiran Teoritis

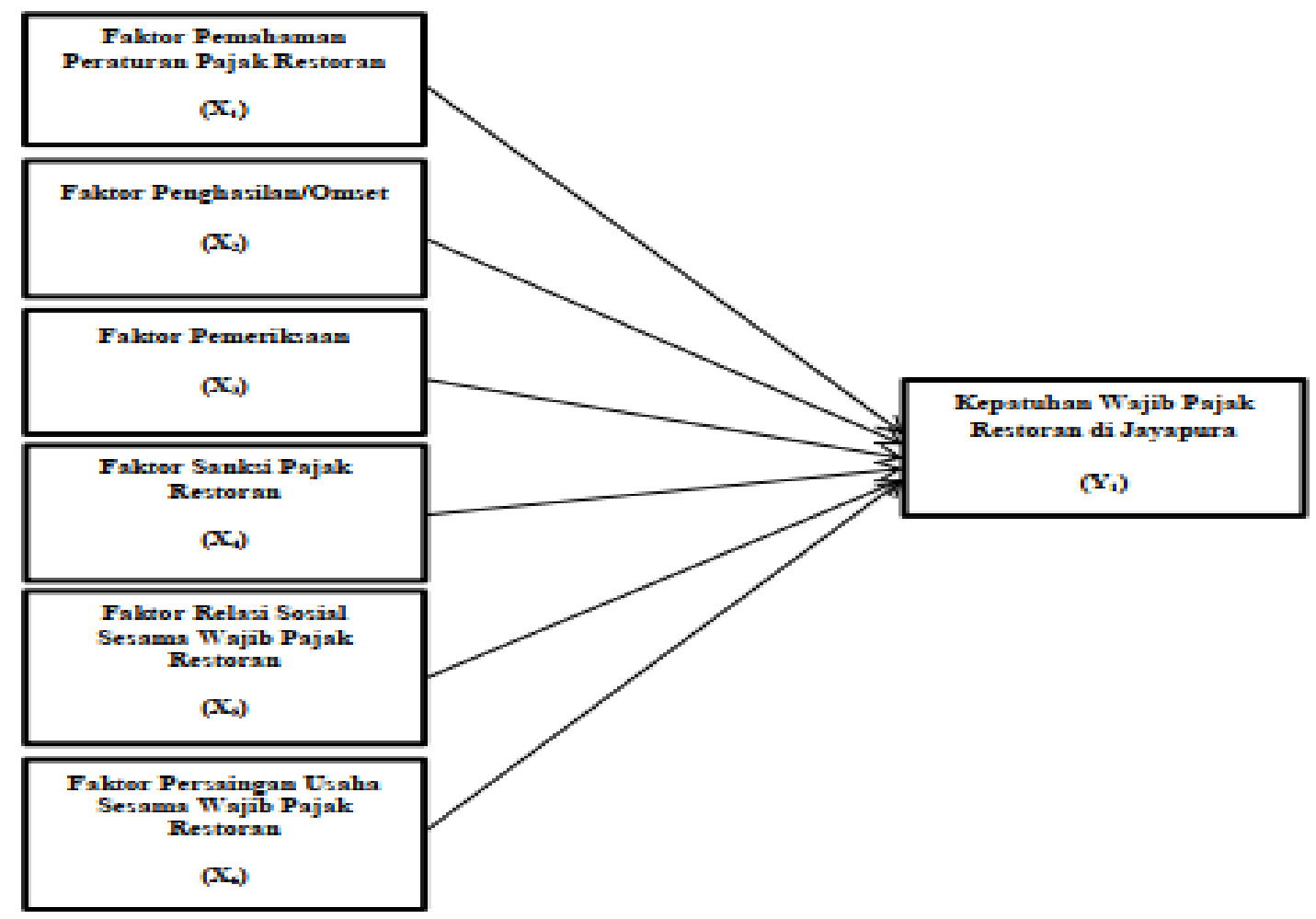

Sumber: Penulis 2019 


\section{METODOLOGI PENELITIAN}

\subsection{Populasi dan Sampel}

Populasi dari penelitian ini adalah semua wajib pajak restoran yang terdaftar di Dinas Pendapatan Daerah Kota Jayapura. Populasi yang digunakan dalam penelitian adalah wajib pajak orang pribadi (WPOP) yang hanya mendapatkan penghasilan tetap dan mempunyai usaha serta kriteria wajib pajak yang digunakan adalah wajib pajak yang terdaftar dan aktif dalam melakukan kewajiban perpajakan dan memiliki NPWP. Sampel dari penelitian ini adalah seluruh jumlah populasi yaitu restoran yang terdaftar di Dinas Pendapatan Daerah Kota Jayapura.

\subsection{Jenis dan Sumber Data}

Jenis data yang digunakan dalam penelitian ini adalah data primer. Data primer yaitu data yang berasal langsung dari sumber data yang dikumpulkan secara khusus dan berhubungan langsung dengan permasalahan yang diteliti. Sumber data primer dalam penelitian ini diperoleh dari para WP yang ada di Kota Jayapura. Data ini berupa kuesioner yang nantinya akan diisi oleh para Wajib Pajak yang menjadi responden terpilih dalam penelitian ini. Sejumlah pernyataan diajukan kepada responden dan kemudian responden yang sempat dan bersedia langsung untuk menjawab sesuai dengan pendapat mereka. Untuk mengukur pendapat responden digunakan skala lima angka yaitu. mulai angka 5 untuk pendapat sangat setuju (SS) dan angka 1 untuk sangat tidak setuju (STS). Perinciannya adalah sebagai berikut : Angka 1 = Sangat Tidak Setuju (STS) Angka $2=$ Tidak Setuju (TS) Angka 3 = Netral (N) Angka $4=$ Setuju (S) Angka $5=$ Sangat Setuju (SS).

\subsection{Metode Pengumpulan Data}

Metode pengumpulan data yang digunakan dalam penelitian ini adalah melalui kuesioner yang berupa angket. Jenis kuesioner yang digunakan kuesioner tertutup. Kuesioner tertutup dalam penelitian adalah pertanyaanpertanyaan yang harus dipilih oleh responden dari berbagai pilihan jawaban yang tersedia. Pengambilan sampel dilakukan dengan metode convenience sampling. Dalam pengambilan sampel berdasarkan akses yang dapat dijangkau oleh peneliti dalam menyebarkan kuisioner.

\subsection{Teknik Analisis Data}

Metode analisis data yang dilakukan yaitu uji statistik deskriptif, uji asumsi klasik, uji kualitas instrumen dan menggunakan analisis regresi linear berganda dengan menggunakan SPSS.

Analisis regresi berganda ialah hubungan secara linear antara dua atau lebih variabel independen (X1,X2,X3,X4,X5,X6) dengan variabel dependen (Y). Analisis ini dilakukan untuk mengetahui arah hubungan antara variabel independen dengan variabel dependen apakah masingmasing variabel independen berhubungan positif atau negatif dan untuk memprediksi nilai dari variabel dependen apabila nilai variabel independen naik atau turun. Dalam penelitian ini peneliti menggunakan analisis linear berganda dengan 6 variabel independen yang dapat dinyatakan dalam persamaan sebagai berikut:

$$
\mathrm{Y}=\alpha+\beta 1 \mathrm{X} 1+\beta 2 \mathrm{X} 2+\beta 3 \mathrm{X3}+\beta 4 \mathrm{X} 4+\beta 5 \mathrm{X} 5+\beta 6 \mathrm{X} 6+\mathrm{e}
$$

\section{Keterangan:}

Y : Kepatuhan Wajib Pajak Restoran

$\boldsymbol{\alpha}:$ Konstanta

$\boldsymbol{\beta}$ : Koefisien regresi untuk masing-masing variabel independen

X1 : Pemahaman Peraturan Perpajakan

X2 : Omset/Penghasilan Wajib Pajak Restoran

X3 : Pemeriksaan

X4 : Sanksi Perpajakan 


\section{HASIL PENELITIAN DAN PEMBAHASAN}

\subsection{Gambaran Umum Responden}

Penelitian ini dilakukan di beberapa restoran yang terdaftar di Badan pendapatan Kota Jayapura, Jumlah keseluruhan kuesioner yang disebar dalam penelitian ini adalah 100 kuesioner. Penyebaran kuesioner dilakukan secara langsung dengan cara menunggu responden saat pengisian kuesioner dan langsung mengumpulkan kuesioner yang telah diisi. Tingkat kuesioner yang kembali adalah $100 \%$. Total kuesioner yang dapat diolah dalam penelitian ini adalah $100 \%$ atau 100 kuesioner yang disebar.

Berikut ini adalah karakteristik identitas responden:

Tabel 1

Statistik Responden

\begin{tabular}{|c|c|c|c|}
\hline $\mathrm{No}$ & Keterangan & Jumlah & Persentase \\
\hline 1. & $\begin{array}{l}\text { Wajib Pajak Badan } \\
\text { Restoranyang Terdaftar di } \\
\text { Badan Pendapatan Kota } \\
\text { Jayapura. }\end{array}$ & 100 & 100 \\
\hline 2 & $\begin{array}{l}\text { Lama Beroperasi: } \\
\begin{aligned} & \text { 1-10 Tahm } \\
\text { - } & 11-20 \text { Tabm } \\
\text { - } & \text { 21-30 Tabm }\end{aligned}\end{array}$ & $\begin{array}{l}74 \\
17 \\
9\end{array}$ & $\begin{array}{l}74 \% \\
179 \\
9 \%\end{array}$ \\
\hline 3 & $\begin{aligned} \text { Jumlah Faryawan }= \\
+1-5 \\
* \quad 6-10 \\
+10-15\end{aligned}$ & $\begin{array}{l}81 \\
10 \\
9\end{array}$ & $\begin{array}{l}81 \% \\
10 \% \\
9 \%\end{array}$ \\
\hline 4 & 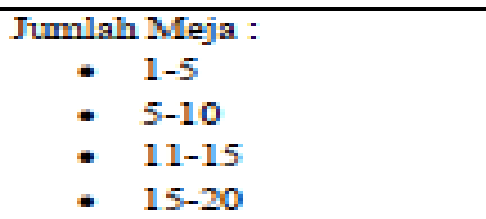 & $\begin{array}{l}52 \\
34 \\
11 \\
3\end{array}$ & $\begin{array}{l}5296 \\
3496 \\
1196 \\
396\end{array}$ \\
\hline 5. & $\begin{array}{l}\text { Menerima catering } \\
\begin{array}{l}\text { - Ya } \\
\text { - Tidal }\end{array}\end{array}$ & $\begin{array}{l}61 \\
39\end{array}$ & $\begin{array}{l}61 \% \\
390 \%\end{array}$ \\
\hline 6. & $\begin{array}{l}\text { Pendapatan Restoran Per } \\
\text { Tahma } \\
\text { * } 10-20 \text { Juta Tabum } \\
\text { * } 21-30 \text { Juta Tabum } \\
\text { * } \quad 41-40 \text { Juta Tabum }\end{array}$ & $\begin{array}{l}51 \\
24 \\
14 \\
11\end{array}$ & $\begin{array}{l}51 \% \\
24 \% \\
14 \% \\
119 \%\end{array}$ \\
\hline 7 & $\begin{array}{c}\text { Lama menilili NPWP = } \\
\text { * } 1-5 \text { Tahm } \\
\text { * } 6-10 \text { Tahm } \\
* 10 \text { Tahm }\end{array}$ & $\begin{array}{l}56 \\
31 \\
13\end{array}$ & $\begin{array}{l}5696 \\
3196 \\
1396\end{array}$ \\
\hline
\end{tabular}




\subsection{Statistik Deskriptif}

Pada tabel 2 dibawah ini dapat di lihat bahwa variable Dependen Kepatuhan wajib pajak memiliki nilai terendah sebesar 22,00 dan nilai tertinggi sebesar 30,00 dengan nilai rata-ratanya sebesar 25,52 dan standar deviasinya (tingkat sebaran data) sbesar 2,20. Variabel independen Pemahaman Peraturann memiliki nilai terendah sebesar 24,00 dan nilai tertinggi sebesar 35,00 dengan nilai rataratanya sebesar 29,82 dan standar deviasinya sebesar 2,54. Variabel independen Omset memilki nilai terendah sebesar 26.00 dan nilai tertinggi sebesar 35,00 dengan nilai rata-ratnya sebesarnya 30,11 dan standar deviasinya sebesar 2,42. Variabel independen Pemeriksaan memiliki nilai terendah sebesar 10,00 dan nilai tertingginya sebesar 19.00 dengan nilai rata-ratanya sebesar 13,97 dan standar deviasinya sebesar 1,75. Variabel independen Sanksi Pajak Memiliki nilai terendah sebesar 10,00 dan nlai tertingginya sebesar 19.00 dengan nilai rataratanya 13,85 dan standar deviasinya sebesar 1,70. Variabelnya independen Relasi Sosial memiliki nilai terendah sebesar 15,00 dan nilai tertingginya sebesar 30,00 dengan nilai rata-ratanya 21,42 dan standar deviasinya sebesar 3,49. Variabel Independen Persaingan Usaha memiliki nilai terrendah sebesar 16,00 dan nilai Tertinggnya sebesar 25,00 dengan nilai rata-ratanya 19,50 dan standar deviasinya sebesar 2,05.

\section{Tabel 2}

\section{Tabel Statistik Deskriptif}

\begin{tabular}{|l|r|r|r|r|r|}
\hline \multicolumn{7}{|c|}{ Descriptive Statistics } & \multicolumn{1}{c|}{ Std. } \\
& $N$ & Minimum & Maximum & \multicolumn{1}{c|}{ Mean } & Deviation \\
\hline PEMAHAMAN & 100 & 24.00 & 35.00 & 29.8200 & 2.54010 \\
PERATURAN & 100 & 26.00 & 35.00 & 30.1100 & 2.42418 \\
OMSET & 100 & 10.00 & 19.00 & 13.9700 & 1.75496 \\
PEMERIKSAAN & 100 & 10.00 & 19.00 & 13.8500 & 1.70190 \\
SANKSI PAJAK & 100 & 15.00 & 30.00 & 21.4200 & 3.49366 \\
RELASI SOSIAL & 100 & 16.00 & 25.00 & 19.5000 & 2.05235 \\
PERSAINGAN USAHA & 100 & 22.00 & 30.00 & 25.5200 & 2.20871 \\
KEPATUHAN WAJIB & 100 & & & & \\
PAJAK & & & & \\
Valid N (listwise) & & & & &
\end{tabular}

Sumber : Data diolah SPSS 23, 2019

\subsection{Analisis Regresi Linear Berganda}

Variabel bebas dalam penelitian ini terdiri dari Pemahaman Peraturan (X1),Omset(X2),Pemeriksaan(X3),Sanksipajak(X4),RelasiSosial(X5),Persaingan Usaha dengan Variabel terikat Kepatuhan Wajib Pajak (Y).

Persamaan regresi linear dalam penelitian ini adalah :

$\mathrm{Y}=1,341-0,350 \mathrm{X} 1+0,306 \mathrm{X} 2+0,203 \mathrm{X} 3+0,077 \mathrm{X} 4-0,132 \mathrm{X} 5+0,177 \mathrm{X} 6+0,05$ Berdasarkan tabel diatas, dengan tarif signifikan sebesar $5 \%(0,05)$ maka nilai signifikan untuk konstanta sebesar 0,749 , dengan demikian dapat dinyatakan bahwa konstanta berpengaruh tidak signifikan terhadap model regresi. Nilai signifikansi dari masing-masing variabel X1 sebesar 0,000,variabel X2 sebesar 0,002, variabel X3 sebesar 0,144,variabel X4 sebesar 0,583,Variabel X5 sebesar 0,118 dan Variabel X6 sebesar 0,186 maka dapat disimpulkan bahwa variabel X1 dan $\mathrm{X} 2<0,05$ mempumyai pengaruh yang signifikan terhadap $\mathrm{Y}$, sedangkan variabel $\mathrm{X} 3$, X4,X5 dan $\mathrm{X} 6>0,05$ tidak mempunyai pengaruh yang signifikan secara parsial terhadap $\mathrm{Y}$. 


\subsection{Hasil Pengujian Hipotesis}

Uji Signifikansi Parsial ( Uji t)

Tabel 3

Uji signifikan Parsial ( Uji t)

\begin{tabular}{|c|c|c|c|c|c|c|}
\hline \multicolumn{7}{|c|}{ Coefficients $^{a}$} \\
\hline \multirow{2}{*}{\multicolumn{2}{|c|}{ Moclel }} & \multicolumn{2}{|c|}{$\begin{array}{l}\text { Unstandardized } \\
\text { Coefficients }\end{array}$} & \multirow{2}{*}{$\begin{array}{c}\begin{array}{c}\text { Standardiz } \\
\text { ed } \\
\text { Coefficients }\end{array} \\
\text { Beta }\end{array}$} & \multirow[b]{2}{*}{$\mathrm{t}$} & \multirow[b]{2}{*}{ Sig. } \\
\hline & & B & Std. Error & & & \\
\hline 1 & (Constant) & 1.341 & 4.181 & & .321 & .749 \\
\hline & $\begin{array}{l}\text { PEMAHAMAN } \\
\text { PERATURAN }\end{array}$ & .350 & .089 & .402 & 3.942 & .000 \\
\hline & OMSET & .306 & .094 & .335 & 3.259 & .002 \\
\hline & PEMERIKSAAN & .203 & -138 & .162 & 1.472 & .144 \\
\hline & SANKSI PAJAK & .077 & -140 & .059 & .551 & .583 \\
\hline & RELASI SOSIAL & -.132 & .084 & -.209 & -1.578 & .118 \\
\hline & $\begin{array}{l}\text { PERSAINGAN } \\
\text { USAHA }\end{array}$ & .177 & .133 & .165 & 1.333 & .186 \\
\hline
\end{tabular}

a. Dependent Variable: KEPATUHAN WAJIB PAJAK

Sumber: Data diolah SPSS 23,2019

Diketahui nilai sig untuk pengaruh X1 terhadap $\mathrm{Y}$ adalah sebesar $0,000<0,05 \&$ nilai t hitung 3,942 > -1,985 sehingga dapat disimpulkan $\mathrm{H}_{1}$ diterima yang berarti terdapat pengaruh antara X1 terhadap Y (Berpengaruh Positif). Diketahui nilai sig untuk pengaruh X2 terhadap Y adalah sebesar $0,002<0,05 \&$ nilai $\mathrm{t}$ hitung 3,259>-1,985 sehingga dapat disimpulkan $\mathrm{H}_{2}$ diterima yang berarti terdapat pengaruh antara X2 terhadap Y (Berpengaruh Positif). Diketahui nilai sig untuk pengaruh X3 terhadap Y adalah sebesar 0,144 > 0,05 \& nilai t hitung 1,472 < 1,985 sehingga dapat disimpulkan $\mathrm{H}_{3}$ ditolak yang berarti tidak terdapat pengaruh $\mathrm{X} 3$ terhadap $\mathrm{Y}$ (Tidak Berpengaruh Positif). Diketahui nilai sig untuk pengaruh X4 terhadap Y adalah sebesar 0,583>0,05 \& nilai thitung $0,551<1,985$ sehingga dapat disimpulkan $\mathrm{H}_{4}$ ditolak yang berarti tidak terdapat pengaruh $\mathrm{X} 4$ terhadap Y (Tidak Berpengaruh Positif). Diketahui nilai sig untuk pengaruh X5 terhadap Y adalah sebesar $0,188>0,05 \&$ nilai $\mathrm{t}$ hitung $-1,578<1,985$ sehingga dapat disimpulkan $\mathrm{H}_{5}$ ditolak yang berarti tidak terdapat pengaruh X5 terhadap Y (Tidak Berpengaruh Negatif). Diketahui nilai sig untuk pengaruh X6 terhadap Y adalah sebesar 0,186 > 0,05 \& nilai t hitung 1,333 < 1,985 sehingga dapat disimpulkan $\mathrm{H}_{6}$ ditolak yang berarti tidak terdapat pengaruh X6 terhadap Y (Tidak Berpengaruh Positif).

\section{Uji Signifikansi Simultan (Uji f)}

Uji $F$ dilakukan dengan tujuan untuk mengetahui apakah variabel Pemahaman Peraturan,Omset,Pemeriksaan,Sanksi Pajak,Relasi Sosial dan Persaingan Usaha secara bersama-sama berpengaruh terhadap Kepatuhan Wajib Pajak (Y). Jika Fhitung > Ftabel dan nilai signifikansi $<0.05$ maka dapat disimpulkan bahwa variabel bebas berpengaruh terhadap variabel terikat.

Berdasarkan tabel pengujian dibawah ini, menunjukan hasil nilai fhitung sebesar 7,165 > 2,20 dan nilai signifikansi $0,000<0,05$. Hal ini menunjukan variabel bebas secara bersama-sama (simultan) mempunyai pengaruh yang signifikan terhadap Kepatuhan Wajib Pajak dalam penelitian ini 
Tabel 4

Uji signifikansi Simultan (Uji f)

\begin{tabular}{|l|r|r|r|r|r|}
\hline \multicolumn{7}{|c|}{ ANOVA $^{2}$} \\
\hline Model & \multicolumn{1}{|c|}{$\begin{array}{c}\text { Sum of } \\
\text { Squares }\end{array}$} & \multicolumn{1}{c|}{ Df } & Mean Square & F & Sig. \\
\hline Regression & 152.672 & 6 & 25.445 & 7.165 & $.000^{\circ}$ \\
Residual & 330.288 & 93 & 3.551 & & \\
Total & 482.960 & 99 & & & \\
& & & & \\
\hline
\end{tabular}

a. Dependent Variable: KEPATUHAN WAJIB PAJAK

b. Predictors: (Constant), PERSAINGAN USAHA, PEMAHAMAN PERATURAN,

SANKSI PAJAK, OMSET , PEMERIKSAAN, RELASI SOSIAL

\section{Sumber : Data diolah SPSS 23,2019}

\section{Uji Koefisien Determinasi ( $\mathrm{R}_{2}$ )}

Pengujian koefisien determinasi dilakukan untuk mengetahui seberapa besar presentase kontribusi pengaruh variabel bebas secara bersama-sama terhadap variabel terikat.

Tabel 5

Uji Koefisien Determinasi $\left(\mathbf{R}^{2}\right)$

Model Summary

\begin{tabular}{|l|r|r|r|c|}
\hline Model & $\mathbf{R}$ & $\mathbf{R}$ Square & $\begin{array}{c}\text { Adjusted } \mathrm{R} \\
\text { Square }\end{array}$ & \multicolumn{1}{c|}{$\begin{array}{l}\text { Std. Error of the } \\
\text { Estimate }\end{array}$} \\
\hline 1 & .562 & .316 & .272 & \multicolumn{1}{c|}{1.88454} \\
\hline
\end{tabular}

a. Predictors: (Constant), PERSAINGAN USAHA, PEMAHAMAN PERATURAN,

SANKSI PAJAK, OMSET, PEMERIKSAAN, RELASI SOSIAL

\section{Sumber : Data diolah SPSS 23,2019}

\subsection{Pembahasan}

\section{Pengaruh Pemahaman Peraturan Perpajakan Terhadap Kepatuhan Wajib Pajak}

Hasil pengujian yang diperoleh dalam penelitian ini menyatakan Variabel pemahaman peraturan mempunyai pengaruh terhadap kepatuhan wajib pajak yang ada di kantor Bapenda kota Jayapura. Berdasarkan hasil uji t dari variabel Pemahaman Peraturan diketahui nilai sig untuk pengaruh X1 terhadap Y sebesar $0,000<0,05$ maka terjadi koefisien positif dan signifikan antara Pemahaman Peraturan dengan Kepatuhan Wajib Pajak. Hal ini berarti bahwa Pemahaman Peraturan yang baik berpengaruh dalam meningkatkan tingkat Kepatuhan Wajib Pajak.

Hasil penelitian ini sesuai dengan penelitian yang dilakukan oleh Arviana \& Sadjiarto (2014) yang menyatakan bahwa pemhaman peraturan berpengaruh signifikan terhadap Kepatuhan Wajib Pajak. Penelitian yang di lakukan oleh Trisnawati \& Sudirman (2015) menyatakan bahwa pemahaman peraturan berpengaruh signifikan terhadap tingkat Kepatuhan Wajib Pajak. Dalam penelitian tersebut menjelaskan,apabila wajib pajak memiliki Pemahaman dan Pengetahuan yang baik mengenai 


\section{Pengaruh Omset/Penghasilan Terhadap Kepatuhan Wajib Pajak}

Hasil pengujian yang diperoleh dalam penelitian ini menyatakan Variabel Omset/Penghasilan mempunyai pengaruh terhadap kepatuhan wajib pajak yang ada di kantor Bapenda kota Jayapura. Berdasarkan hasil uji t dari variabel Omset diketahui nilai sig untuk pengaruh X2 terhadap Y sebesar $0,002<0,05$ maka terjadi koefisien positif dan signifikan antara Omset dengan Kepatuhan Wajib Pajak. Hal ini berarti bahwa Omset berpengaruh dalam meningkatkan tingkat Kepatuhan Wajib Pajak.

Hasil penelitian ini sesuai dengan penelitian Arviana \& Sadjiarto (2014) Menyatakan omset berpengaruh signifikan terhadap kepatuhan wajib pajak. dalam penelitian Rizajayanti (2017) tersebut menyatakan bahwa omset berpengaruh signifikan.faktor yang dianggap mempengaruhi kepatuhan wajib pajak karena wajib pajak cenderung menyembunyikan omset penjualanya.hal inii di karenakan wajibpajak merasa keberatan atas tarif yang di tetapkan dari besarnya omset. Menurut Nugroho (2012) control beliefs. Tingkat omset juga mempengaruhi kepatuhan wajib pajak dalam membayar pajak tepat waktu dan memiliki hubungan terhadap kemampuan wajib pajak dalam memenuhi kewajiban perpajakannya.

\section{Pengaruh PemeriksaanTerhadap Kepatuhan Wajib Pajak}

Hasil pengujian yang diperoleh dalam penelitian ini menyatakan Variabel Pemeriksaan tidak mempunyai pengaruh terhadap kepatuhan wajib pajak yang ada di kantor Bapenda kota Jayapura. Berdasarkan hasil uji t dari variabel Pemeriksaan diketahui nilai sig untuk pengaruh X3 terhadap Y sebesar 0,144>0,05 maka menyatakan bahwa X3 koefisien positif dan tidak signifikan antara pemeriksaan dan kepatuhan wajib pajak .Hal ini berarti bahwa semakin baik tingkat pemeriksaan aparat pajak tidak berpengaruh terhadap tingkat kepatuhan wajib pajak.

Hasil penelitian ini sejalan dengan penelitian Arviana \& Sadjiarto ( 2014) yang menyimpulkan bahwa pemeriksaan aparat pajak tidak berpengaruh terhadap kepatuhan wajb pajak.dan menyatakan bahwa pengelolaan pajak restoran telah diaturdengan adanya pemeriksaan yang berlaku, namun belum efektif karena kendala jumlah petugas lapangan tidak sebanding dengan restoran yang ada di kota samarinda.

\section{Pengaruh Sanksi Perpajak terhadap Kepatuhan Wajib Pajak}

Hasil pengujian yang diperoleh dalam penelitian ini menyatakan variabel Sanksi Perpajakan tidak mempunyai pengaruh terhadap kepatuhan wajib pajak yang ada di kantor Bapenda kota Jayapura. Berdasarkan hasil uji t dari variabel Sanksi Perpajakan diketahui nilai sig untuk pengaruh $\mathrm{X} 4$ terhadap $\mathrm{Y}$ sebesar 0,583 > 0,05 maka terjadi koefisien positif dan tidak signifikan antara sanksi perpajakan dengan Kepatuhan Wajib Pajak. Hal ini berarti bahwa semakin berat sanksi perpajakan yang diberikan tidak berpengaruh positif terhadap Kepatuhan wajib pajak. Hal ini sesuai dengan penelitian yang dilakukan oleh Dwiastari, (2017) yang menyimpulkan bahwa sanksi perpajakan tidak berpengaruh terhadap persepsi wajib pajak mengenai kepatuhan wajib pajak.

Penelitian yang dilakukan oleh Arviana \& Sadjiarto (2014) menunjukan hal yang serupa bahwa sanksi perpajakan tidak berpengaruh, hal ini menunjukan bahwa pengenaan sanksi perpajakan kepada pelanggar peraturan perpajakan tidak memberikan banyak pengaruh terhadap persepsi wajib pajak mengenai kepatuhan wajib pajak. 


\section{Pengaruh Relasi sosial Terhadap Kepatuhan Wajib Pajak}

Hasil pengujian yang diperoleh dalam penelitian ini menyatakan Variabel Sanksi Perpajakan tidak mempunyai pengaruh terhadap kepatuhan wajib pajak yang ada di kantor Bapenda kota Jayapura. Berdasarkan hasil uji t dari variabel Sanksi Perpajakan diketahui nilai sig untuk pengaruh X5 terhadap Y sebesar 0,188>0,05 maka terjadi koefisien negatif dan tidak signifikan antara Relasi Sosial dengan Kepatuhan Wajib Pajak.dan relasi sosial tidak saling mempengaruhi antara relasi dan kepatuhan wajib pajak. Relasi sosial tidak membawa pengaruh yang diberikan dari Wajib Pajak yang satu kepada Wajib Pajak yang lain termasuk dalam memenuhi kewajiban perpajakannya.

Penelitian yang di lakukan oleh Arviana \& Sadjiarto (2014) menunjukan hal yang serupa bahwa relasi sosial tidak berpengaruh,hal ini menunjukan bahwa relasi sosial tidak meningkatkan tingkat kepatuhan wajib pajak.Penelitian ini bertolak belakang dengan penelitian yang dilakukan oleh Dwiastari (2017) yang mengemukakan Hasil penelitian diketahui bahwa Relasi Sosial berpengaruh Signifikan terhadap kepatuhan Wajib pajak.

\section{Pengaruh Persaingan Usaha Terhadap Kepatuhan Wajib Pajak}

Hasil pengujian yang diperoleh dalam penelitian ini menyatakan Variabel Sanksi Perpajakan tidak mempunyai pengaruh terhadap kepatuhan wajib pajak yang ada di kantor Bapenda kota Jayapura. Berdasarkan hasil uji t dari variabel Persaingan Usaha diketahui nilai sig untuk pengaruh X6 terhadap Y sebesar 0,186>0,05 maka terjadi koefisien positif dan tidak signifikan antara Persaingan Usaha dengan Kepatuhan Wajib Pajak. Hal ini berarti bahwa semakin banyak persaingan usaha tidak berpengaruh terhadap tingkat kepatuhan wajib pajak.

Penelitan yang dilakaukan Arviana \& Sadjiarto (2014) menujukan hal yang serupa bahwa persaingan usaha tidak memberikan pengaruh terhadap kepatuhan wajib pajak. Nugroho (2012) menambahkan hal-hal yang dapat menghambat saat prilaku ditampilkan dapat berasal dari dalam diri. Secara berurutan, behavioral beliefs menghasilkan sikap positif atau negatif pada suatu objek. yang dapat mempengaruhi penentuan perilaku suatu individu. Penelitian ini menunjukkan tidak berpengaruh signifikan persaingan usaha antar restoran terhadap tingkat kepatuhan Wajib Pajak dalam memenuhi kewajibannya.

\section{PENUTUP}

\subsection{Kesimpulan}

Berdasarkan pada data yang telah dikumpulkan dan hasil pengujian yang telah diperoleh maka dapat diambil kesimpulan sebagai berikut:

a. Pengujian Hipotesis Pertama yang dilakukan membuktikan bahwa secara parsial Pemahaman Peraturan berpengaruh terhadap Kepatuhan wajib Pajak di lihat dari nilai sig untuk pengaruh X1 terhadap $\mathrm{Y}$ adalah sebesar $0,000<0,05 \&$ nilai t hitung 3,942 > -1,985 akan dapat dikatakan mempunyai pengaruh signifikan antara variabel pemahaman peraturan terhadap kepatuhan wajib pajak.

b. Pengujian hipotesis kedua yang dilakukan bahwa secara parsial omset/penghasilan mempunyai pengaruh yang signifikan dilhat dari nilai sig untuk pengaruh $\mathrm{X} 2$ terhadap $\mathrm{Y}$ adalah sebesar $0,002<0,05 \&$ nilai t hitung 3,259 > -1,985 akan dapat dikatakan mempunyai pengaruh signifikan antara variabel omset/penghasilan terhadap Kepatuhan wajib pajak.

c. Pengujian hipotesis ketiga yang dilakukan bahwa secara parsial pemeriksaan tidak berpengaruh terhadap kepatuhan wajib pajak dilihat dari nilai sig untuk pengaruh $\mathrm{X} 3$ terhadap $\mathrm{Y}$ adalah sebesar $0,144>0,05 \&$ nilai t hitung $1,472<1,985$ akan dapat dikatakan tidak mempunyai pengaruh signifikan antara variabel pemeriksaan terhadap kepatuhan wajib pajak.

d. Pengujian hipotesis kempat yang dilakukan bahwa secara parsial sanksi pepajakan tidak berpengaruh terhadap kepatuhan wajib pajak dilihat dari nilai nilai sig untuk pengaruh $\mathrm{X} 4$ terhadap $\mathrm{Y}$ 
adalah sebesar 0,583 > 0,05 \& nilai t hitung 0,551 < 1,985 akan dapat dikatakan tidak mempunyai pengaruh signifikan antara sanksi perpajakan terhadap kepatuhan wajib pajak

e. Pengujian hipotesis kelima yang dilakukan bahwa secara parsial relasi sosial tidak berpengaruh terhadap kepatuhan wajib pajak dilihat dari nilai sig untuk pengaruh X5 terhadap Y adalah sebesar $0,188>0,05 \&$ nilai t hitung $-1,578<1,985$ akan dapat dikatakan tidak mempunyai pengaruh signifikan antara relasi sosial terhadap kepatuhan wajib pajak

f. Pengujian hipotesis keenam yang dilakukan bahwa secra parsial persaingan usaha tidak berpengaruh terhadap kepatuhan wajib pajak dilihat dari nilai sig untuk pengaruh X6 terhadap Y adalah sebesar $0,186>0,05 \&$ nilai t hitung 1,333 < 1,985 akan dapat dikatakan tidak memepunyai pengaruh signifikan antara persaingan usaha terhadap kepatuhan wajib pajak.

\section{DAFTAR PUSTAKA}

Adiningrat, A. A., Subhan, \& Nur, M. (2017). Analisis Kontribusi Pemungutan Pajak Hotel dan Restoran Terhadap Pendapatan Asli Daerah di DISPENDA Kota Makassar. Perspektif.

Arviana, N., \& Sadjiarto, A. (2014). Pengaruh Pemahaman Peraturan, Omset, Pemeriksaan, Sanksi, Relasi sosial, dan Persaingan Usaha Terhadap Kepatuhan Wajib Pajak Restoran di Mojokerto Tahun 2014. Tax \& Accounting Review.

Aryobimo, P. T., \& Cahyonowati, N. (2012). Pengaruh Persepsi Wajib Pajak tentang Kualitas Pelayanan Fiskus terhadap Kepatuhan Wajib Pajak dengan Kondisi Keuangan Wajib Pajak dan Preferensi Risiko sebagai Variabel Moderating (Studi Empiris terhadap Wajib Pajak Orang Pribadi di Kota Semarang). Diponegoro Journal Of Accounting, 1(2), 1-12.

Bobek, D. D., Hageman, A. M., \& Hatfield, R. C. (2010). The Role of Client Advocacy in the Development of Tax Professionals' Advice. The Journal of the American Taxation Association. https://doi.org/10.2308/jata.2010.32.1.25

Bobek, D. D., \& Hatfield, R. C. (2008). An Investigation of the Theory of Planned Behavior and the Role of Moral Obligation in Tax Compliance. Behavioral Research in Accounting. https://doi.org/10.2308/bria.2003.15.1.13

Dwiastari, I. (2017). Pengaruh Pemahaman Peraturan, Omset, Sanksi, dan Relasi Sosial terhadap Kepatuhan Wajib Pajak.

Ghozali, I. (2006). Aplikasi analisis multivariate dengan program SPSS. Badan Penerbit Universitas Diponegoro.

Hardiningsih, P., \& Yulianawati, N. (2011). Faktor-Faktor Yang Mempengaruhi Kemauan Membayar Pajak. Dinamika Keuangan Dan Perbankan. https://doi.org/ISSN: 1979-4878

Jatmiko, A. N. (2006). Pengaruh Sikap Wajib Pajak Pada Pelaksanaan Sanksi Denda, Pelayanan Fiskus dan Kesadaran Perpajakan Terhadap Kepatuhan Wajib Pajak ( Studi Empiris Terhadap Wajib Pajak Orang Pribadi di Kota Semarang ). Tesis.

Jaya, I. B. M., \& Jati, I. K. (2016). Pengaruh Kesadaran, Kualitas Pelayanan, Pemeriksaaan dan Sanksi Perpajakan Pada Kepatuhan Wajib Pajak Restoran. E-Jurnal Akuntansi Universitas Udayana. KBBI. (2014). Kamus Besar Bahasa Indonesia (KBBI) Online - definisi kata. Potensi. https://doi.org/kamus

Kumalayani, P. A., Sukarsa, M., \& Yasa, I. N. M. (2016a). Kebijakan Dan Kemudahan Administrasi Pajak terhadap Kepatuhan Membayar Pajak Hotel dan Restoran di Kabupaten Badung, 5, 11711196.

Kumalayani, P. A., Sukarsa, M., \& Yasa, I. N. M. (2016b). KEBIJAKAN DAN

KEMUDAHAN ADMINISTRASI PAJAK TERHADAP KEPATUHAN MEMBAYAR PAJAK HOTEL DAN RESTORAN DI KABUPATEN BADUNG Fakultas Ekonomi dan Bisnis Universitas Udayana ( Unud ), Bali , Indonesia Kesejahteraan rakyat menjadi fokus pemerintah dalam 
menyelenggar, 5, 1171-1196.

Mardiasmo. (2009). Pengaruh Pelaksanaan Pemeriksaan Pajak Terhadap Kepatuhan Wajib Pajak Badan Berdasarkan Persepsi Pemeriksaan Pajak dan Wajib Pajak (Studi Kasus pada KPP Pratama Bandung Cicadas).

Muliari, N. K., \& Setiawan, P. E. (2011). Pengaruh Persepsi Tentang Sanksi Perpajakan Dan Kesadaran Wajib Pajak Pada Kepatuhan Pelaporan Wajib Pajak Orang Pribadi di Kantor Pelayanan Pajak Pratama Denpasar Timur. Jurnal Ilmiah Akuntansi Dan Bisnis. https://doi.org/23031018

Nugroho, A. (2012). Analisis pengaruh pajak daerah dan retribusi daerah terhadap pendapatan asli daerah kabupaten/kota di Provinsi Jawa Tengah Periode 2010-2012. Jurnal Akuntansi.

Nurlaela, S. (2014). Pengaruh pengetahuan dan pemahaman, kesadaran, persepsi terhadap kemauan membayar pajak wajib pajak orang pribadi yang melakukan pekerjaan bebas. Jurnal Paradigma.

Nurmantu, safri. (2010). Pengantar perpajakan. In Pengantar Perpajakan.

Oroh, N. D. (2013). Analisis Faktor-Faktor Yang Mempengaruhi WP Restoran Melaporkan Kewajiban Perpajakan Di Minahasa. Jurnal EMBA: Jurnal Riset Ekonomi, Manajemen, Bisnis Dan Akuntansi, 1(3).

PERDA Kota Jayapura. (2012). Peraturan Daerah Tentang Pajak Daerah Kota Jayapura, 1-28.

Pratama, R. P., Saifi, M., \& ZA, Z. (2016). Efektivitas Penerimaan Pajak Restoran Dan Dalam Meningkatkan Pendapatan Asli Daerah.

Priantara, D., \& Supriyadi, B. (2012). Faktor-faktor yang Mempengaruhi Pengusaha Kecil dan Mikro Mendaftar Menjadi Wajib Pajak Orang Pribadi. Jurnal Akuntansi Dan Keuangan, 13(2), 98-108.

Ratna sari, M. M., \& Afriyanti, N. N. (2012). Pengaruh Kepatuhan Wajib Pajak dan Pemeriksaan Pajak Terhadap Penerimaan PPH Pasal 25/29 Wajib Pajak Badan Pada KPP Pratama Denpasar Timur. Jurnal Akuntansi.

Rizajayanti, diyan sulastika. (2017a). Pengaruh Pemahaman Peraturan, Omset, Kualitas Pelayanan, dan Sanksi Terhadap Kepatuhan Wajib Pajak (Studi Kasus Pada Wajib Pajak Restoran di Kota Pekanbaru).

Rizajayanti, diyan sulastika. (2017b). PENGARUH PEMAHAMAN PERATURAN, OMSET, KUALITAS PELAYANAN, DAN SANKSI TERHADAP KEPATUHAN WAJIB PAJAK (Studi Kasus Pada Wajib Pajak Restoran di Kota Pekanbaru).

Sidik, M. (2002). Optimalisasi Pajak Daerah dan Retribusi Daerah Dalam Rangka Meningkatkan Kemampuan Keuangan Daerah. Makalah Disampaikan Dalam Acara Orasi Ilmiah Dengan Thema "Strategi Meningkatkan Kemampuan Keuangan Daerah Melalui Penggalian Potensi Daerah Dalam Rangka Otonomi Daerah " Acara Wisuda XXI STIA LAN Bandung Tahun Akademik 2001/2002.

Tjahyono, M. B. (2017). Bangun, Sadar, Ayo Berubah! Direktorat Jenderal Pajak Kementrian Keuangan.

Trisnawati, M., \& Sudirman, W. (2015). ANALISIS FAKTOR-FAKTOR YANG MEMPENGARUHI KEPATUHAN WAJIB PAJAK MEMBAYAR PAJAK HOTEL, PAJAK RESTORAN DAN PAJAK HIBURAN DI KOTA DENPASAR Fakultas Ekonomi dan Bisnis Universitas Udayana, Bali , Indonesia Penerimaan pajak daerah salah satu sumber dana pemer, 12, 975-1000. 